\title{
Some mineral, trace element and heavy metal concentrations in newborns with esophageal atresia and their mothers
}

\author{
Mehmet Melek $^{1}$, Halit Demir ${ }^{2}$, Fatih Caglar Celikezen ${ }^{3}$, Nesrin Ceylan ${ }^{4}$, Salim Bilici ${ }^{1}$, Kemal \\ Agengin ${ }^{1}$, Ismet Alkis ${ }^{5}$, Ufuk Cobanoglu ${ }^{6}$, Tugba Gur ${ }^{7}$, Canan Demir ${ }^{7}$, Nihat Demir ${ }^{4}$
}

\begin{abstract}
Objective: The aim was to reveal some minerals, trace elements and heavy metal levels in newborns with esophageal atresia (EA) and their mothers and determine whether there is a relationship between these values and this disease.

Material and Methods: The study included a total of 60 subjects (15 newborns with EA, 15 healthy newborns and their mothers). Blood samples of each subject were obtained. Serum concentrations of copper $(\mathrm{Cu})$, zinc $(\mathrm{Zn})$, magnesium $(\mathrm{Mg})$, manganese $(\mathrm{Mn})$, lead $(\mathrm{Pb})$, cadmium $(\mathrm{Cd})$, and iron $(\mathrm{Fe})$ were determined.

Results: Serum $\mathrm{Mg}, \mathrm{Mn}, \mathrm{Zn}, \mathrm{Cd}, \mathrm{Cu}$ levels were significantly higher in newborns with EA compared to healthy newborns $(\mathrm{p}<0.01)$. Pb level was significantly lower in newborns with EA than those of control group $(p<0.01)$. Serum Cd levels were significantly lower in the mothers of newborns with of healthy newborns. The effect on the infants with EA with higher level of heavy metals was more significant. These changes were limited in their mothers.

Conclusion: These findings may suggest that minerals and heavy metals with the pathogenesis of this disease might interact in the biomolecular level.
\end{abstract}

Keywords: Esophageal atresia, trace elements, heavy metals, newborns.

\section{Introduction}

Esophageal atresia (EA) is a common congenital anomaly occurring in 1:3000-4500 of live births $[1,2]$. In $80-85 \%$ of patients, the lesion consists of an EA with a proximal esophageal pouch and a distal tracheoesophageal fistula (TEF) [3]. Esophageal atresia is an anomaly, or birth defect, of the esophagus which becomes early in pregnancy as baby grows. The esophagus arises in the first few months of fetal living as a long, hollow, continuous tube attending the mouth to the stomach. In newborns with this nursing anomaly, the formation of this continuous esophageal tube is interrupted. It becomes evenly between male and female infants and has been associated to prematurity [4].

Decreases in the levels of zinc $(\mathrm{Zn})$, copper $(\mathrm{Cu})$ and magnesium $(\mathrm{Mg})$ have been implicated in several reproductive incidents like infertility, pregnancy wastage, congenital anomalies, pregnancy induced hypertension, placental abruption, premature rupture of membranes, still births and low birth weight [5]. However, the role of trace elements individually or in combination has not been completely documented in this field.

The purpose of this study was to evaluate some trace element and heavy metal concentrations in newborns with esophageal atresia.

\section{Materials and Methods}

Biochemical Analysis: Subjects were recruited from patients attending the outpatient clinics and those hospitalized in the ward of the Pediatric Surgery Department at Yuzuncu Yil University Hospital. The study included a total of 60 subjects (15 newborns with esophageal atresia, 15 healthy newborns and their mothers). This research received the ethical approval of the local ethics

Received: 13 Oct. 2014, Revised 15 Oct. 2014, Accepted 22 Oct. 2014, Available Online 25 Oct. 2014

${ }^{1}$ Yuzuncu Yil University, Faculty of Medicine, Department of Pediatric Surgery, Van. Turkey.

${ }^{2}$ Yuzuncu Yil University, Faculty of Science, Division of Biochemistry, Department of Chemistry, Van. Turkey.

${ }^{3}$ Bitlis Eren University, Faculty of Art and Science, Division of Biochemistry, Department of Chemistry, Bitlis. Turkey.

${ }^{4}$ Yuzuncu Yil University, Faculty of Medicine, Department of Pediatrics, Van. Turkey.

${ }^{5}$ Yuzuncu Yil University, Faculty of Medicine, Department of Obstetrics and Gynecology, Van. Turkey.

${ }^{6}$ Yuzuncu Yil University, Faculty of Medicine, Department of Thoracic Surgery, Van. Turkey.

${ }^{7}$ Yuzuncu Yil University, Van Vocational School of Health Services, Van. Turkey.

*Corresponding Author: Mehmet Melek E-mail: mmelek44@yahoo.com 
committee. The determination of the levels of the trace elements and heavy metals was performed by the Atomic Absorption Spectrophotometer (UNICAM-929 spectrophotometer, Unicam Ltd, York Street, Cambridge, UK).

Statistical Analysis: Descriptive analyses on focused features are expressed as Average, Standard Dev, Minimum and Maximum values. In order to determine whether there is any difference between groups and Mother-Baby values in terms of variances, the measured variance analysis has been applied. In order to determine the relationship between the mentioned variances, the Spearman correlation coefficient has been calculated. The Statistical significance level has been taken as $\% 5$ and $\% 1$, and SPSS statistical packaged software is used in calculations (SPSS for Windows version 13.0, SPSS Inc., Chicago, Illinois, USA).

Results

$\mathrm{Mg}$ value measured in newborns with EA was higher than that of the control group. It was statistically important as $(p<0.01)$. The increase of serum $\mathrm{Cu}$ level was significantly higher in the newborns with EA than healthy ones $(p<0.01)$. Pb level was detected lower than the control group.-The decrease was statistically significant as $(\mathrm{p}<0.01)$. Serum $\mathrm{Pb}$ levels were not statistically different between mothers of healthy newborns and mothers of newborns with EA. Zn level of EA group was significantly higher than that of the control group $(p<0.01)$. Increased serum $\mathrm{Mn}$ and $\mathrm{Cd}$ levels were determined in EA group compared to the control groups $(\mathrm{p}<0.01)$. Co value was higher in EA but it was not statistically important $(p>0.01)$. In this patient group, serum $\mathrm{Pb}$ and $\mathrm{Cu}$ levels were significantly lower in babies than their mothers $(\mathrm{p}<0.01)$. In the same group, $\mathrm{Cd}$ level was significantly higher in babies than their mothers $(\mathrm{p}<0.01)$. In healthy group, serum $\mathrm{Mg}, \mathrm{Mn}, \mathrm{Zn}$, $\mathrm{Cd}$ and $\mathrm{Cu}$ levels were significantly lower in babies than their mothers $(p<0.01)$. An increase was detected in the concentration of $\mathrm{Fe}$ in the serum of babies with EA. It was higher than the controls group's, but the difference was not statistically significant $(p>0.01)$ (Table 1$)$. In the patient group, a positive correlation determined between $\mathrm{Mg}$ - Fe levels and a negative correlation between $\mathrm{Co}-\mathrm{Fe}, \mathrm{Cd}-\mathrm{Pb}$ levels of babies, a positive correlation between $\mathrm{Pb}-\mathrm{Mg}$, $\mathrm{Cu}-\mathrm{Cd}, \mathrm{Cu}-\mathrm{Fe}$ levels of babies and their mothers were determined. In the same group, there was a positive correlation between $\mathrm{Zn}$ $\mathrm{Mg}, \mathrm{Co}-\mathrm{Zn}, \mathrm{Cd}-\mathrm{Mg}, \mathrm{Cu}-\mathrm{Mg}$ levels of mothers (Table 2).

In the control group, there was a positive correlation between $\mathrm{Zn}-\mathrm{Fe}, \mathrm{Co}-\mathrm{Mg}, \mathrm{Cu}-\mathrm{Mg}$, $\mathrm{Cu}$ - Co levels, a negative correlation between $\mathrm{Co}-\mathrm{Fe}, \mathrm{Cu}-\mathrm{Zn}$ levels of newborns, a positive correlation between $\mathrm{Mg}-\mathrm{Mg}, \mathrm{Zn}-\mathrm{Pb}$, $\mathrm{Cd}-\mathrm{Zn}, \mathrm{Cu}-\mathrm{Cd}$ levels and a negative correlation between $\mathrm{Cu}-\mathrm{Pb}, \mathrm{Cu}-\mathrm{Fe}, \mathrm{Cu}-\mathrm{Zn}$ levels of babies and their mothers. In this group, there was a positive correlation between $\mathrm{Zn}-$ $\mathrm{Mg}, \mathrm{Cu}-\mathrm{Zn}$ levels and a negative correlation between $\mathrm{Zn}-\mathrm{Pb}$ levels of mothers (Table 3 ).

\section{Discussion}

Esophageal atresia (EA) is a condition in which the proximal and distal portions of the esophagus do not communicate. Many variations of this birth anomaly have been described. Newborns with EA often have a

\begin{tabular}{|c|c|c|c|c|}
\hline \multirow[b]{2}{*}{ Parameters } & \multicolumn{2}{|c|}{ Patient Group } & \multicolumn{2}{|c|}{ Healthy Group } \\
\hline & Newborns & Mothers & Newborns & Mothers \\
\hline $\mathrm{Fe}$ (micro g/dI) & $2,089 \pm 0.891$ & $3,011 \pm 1,641$ & $2,497 \pm 0,887$ & $2,397 \pm 1,509$ \\
\hline $\operatorname{Mg}($ micro g/dI) & $20,181 \pm 3.349^{\mathrm{a}}$ & $20,677 \pm 5,054$ & $8,073 \pm 3,312^{\mathrm{a}, \mathrm{c}}$ & $23,051 \pm 3,380^{\mathrm{c}}$ \\
\hline Mn (micro g/dI) & $0,011 \pm 0,007^{\mathrm{a}}$ & $0,013 \pm 0,009$ & $0,005 \pm 0,004^{\mathrm{a}, \mathrm{c}}$ & $0,016 \pm 0,007^{\mathrm{c}}$ \\
\hline $\mathrm{Pb}$ (micro g/dI) & $0,360 \pm 0,121^{\mathrm{a}, \mathrm{c}}$ & $0,690 \pm 0,065^{\mathrm{c}}$ & $0,643 \pm 0,094^{\mathrm{a}}$ & $0,605 \pm 0,163$ \\
\hline $\mathrm{Zn}$ (micro g/dI) & $1,401 \pm 0,379^{\mathrm{a}}$ & $1,203 \pm 0,274$ & $0,812 \pm 0,238^{\mathrm{a}, \mathrm{c}}$ & $1,296 \pm 0,280^{\mathrm{c}}$ \\
\hline Co (micro g/dI) & $0,039 \pm 0,014$ & $0,033 \pm 0,016$ & $0,038 \pm 0,019$ & $0,034 \pm 0,019$ \\
\hline $\mathrm{Cd}$ (micro g/dI) & $0,035 \pm 0,010^{\mathrm{a}, \mathrm{c}}$ & $0,026 \pm 0,010^{\mathrm{b}, \mathrm{c}}$ & $0,019 \pm 0,013^{\mathrm{a}, \mathrm{c}}$ & $0,061 \pm 0,012^{\mathrm{b}, \mathrm{c}}$ \\
\hline $\mathrm{Cu}$ (micro g/dI) & $1,246 \pm 0,768^{\mathrm{a}, \mathrm{c}}$ & $2,009 \pm 0,651^{\mathrm{c}}$ & $0,332 \pm 0,086^{\mathrm{a}, \mathrm{c}}$ & $2,378 \pm 0,470^{\mathrm{c}}$ \\
\hline
\end{tabular}

Data presented as mean \pm SD. $n=15$

$\mathrm{a}_{\mathrm{p}} \leq 0.01, \mathrm{p} \leq 0.05$ compared with healthy newborns, ${ }^{\mathrm{b}} \mathrm{p} \leq 0.01$ compared with healthy mothers, ${ }^{\mathrm{c}} \mathrm{p} \leq 0.05$ compared with mothers in same group; two-factor variance-analysis. 
Table 2. Sperman's rank correlations coefficients between the eight biochemical variables in the newborns with esophageal atresia (n:15) and their mothers (n:15)

$$
\begin{aligned}
& \begin{array}{cccccccccccccccc}
\mathrm{N} & \mathrm{M} & \mathrm{N} & \mathrm{M} & \mathrm{N} & \mathrm{M} & \mathrm{N} & \mathrm{M} & \mathrm{N} & \mathrm{M} & \mathrm{N} & \mathrm{M} & \mathrm{N} & \mathrm{M} & \mathrm{N} & \mathrm{M} \\
\mathrm{Fe} & \mathrm{Fe} & \mathrm{Mg} & \mathrm{Mg} & \mathrm{Mn} & \mathrm{Mn} & \mathrm{P} & \mathrm{Pb} & \mathrm{Zn} & \mathrm{Z} & \mathrm{Co} & \mathrm{Co} & \mathrm{Cd} & \mathrm{Cd} & \mathrm{Cu} & \mathrm{C}
\end{array} \\
& \mathrm{M}-\mathrm{Fe} \quad-, 396 \quad 1 \\
& \mathrm{~N}-\mathrm{Mg} \quad \text { a } \quad-, 118 \quad 1 \\
& \mathrm{M}-\mathrm{Mg} \quad, 187 \quad 090 \quad 222 \quad 1 \\
& \mathrm{~N}-\mathrm{Mn} \quad, 083 \quad 319 \quad, 200 \quad-, 315 \quad 1
\end{aligned}
$$

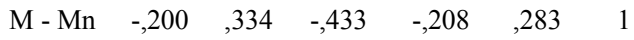

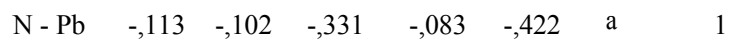

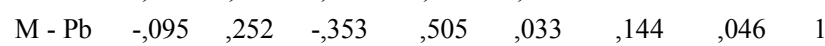

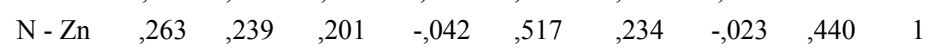

$$
\begin{aligned}
& \begin{array}{lllllllllll}
\mathrm{M}-\mathrm{Zn} & -, 125 & , 097 & -, 172 & \text { a } & -, 119 & , 336 & , 238 & , 412 & -, 051 & 1
\end{array} \\
& \begin{array}{llllllllllll}
\mathrm{N}-\mathrm{Co} & \mathrm{a} & , 425 & -, 122 & -, 215 & , 464 & , 110 & -, 278 & , 002 & , 240 & , 219 & 1
\end{array} \\
& \begin{array}{llllllllllll}
\text { M - Co } & , 080 & -, 342 & , 084 & , 145 & -, 024 & , 287 & , 503 & , 026 & , 037 & \text { a } & , 076
\end{array}
\end{aligned}
$$

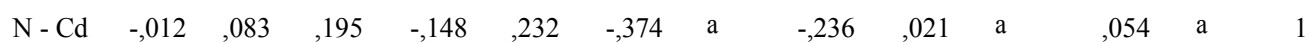

$$
\begin{aligned}
& \begin{array}{lllllllllllllllll}
\mathrm{M}-\mathrm{Cd} & , 146 & -, 314 & -, 169 & \text { a } & -, 526 & -, 164 & , 099 & , 291 & -, 400 & , 127 & \text { a } & -, 002 & -, 104 & 1
\end{array}
\end{aligned}
$$

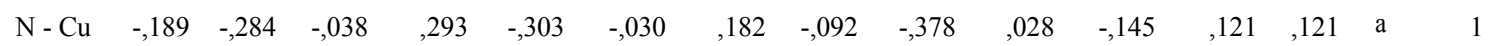

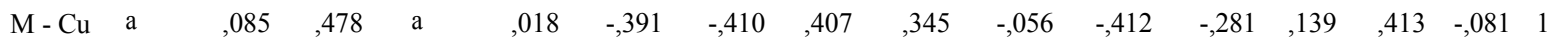

$\mathrm{a}_{*}$ : $\mathrm{p}<0.05, * *: \mathrm{p}<0.01$ (Sperman's rank correlation coefficient).

$\mathrm{N}$, newborn; M, mother; Fe, Iron; Mg, Magnesium; Mn, Manganese; Pb, Lead; Zn, Zinc; Co, Cobalt; Cd,

Cadmium; $\mathrm{Cu}$ Copper

Table 3. Sperman's rank correlations coefficients between the eight biochemical variables in the healthy newborns (n:15) and their mothers $(\mathrm{n}: 15)$

$$
\begin{aligned}
& \begin{array}{lllllllllllllllll}
\mathrm{N} & \mathrm{M} & \mathrm{N} & \mathrm{M} & \mathrm{N} & \mathrm{M} & \mathrm{N} & \mathrm{M} & \mathrm{N} & \mathrm{M} & \mathrm{N} & \mathrm{M} & \mathrm{N} & \mathrm{M} & \mathrm{N} & \mathrm{M}
\end{array} \\
& \begin{array}{lllllllllllllllll}
\mathrm{N}-\mathrm{Fe} & \mathrm{Fe} & \mathrm{Fe} & \mathrm{Mg} & \mathrm{Mg} & \mathrm{Mn} & \mathrm{Mn} & \mathrm{Pb} & \mathrm{Pb} & \mathrm{Zn} & \mathrm{Zn} & \mathrm{Co} & \mathrm{Co} & \mathrm{Cd} & \mathrm{Cd} & \mathrm{Cu} & \mathrm{Cu}
\end{array} \\
& \mathrm{M}-\mathrm{Fe} \quad, 413 \quad 1 \\
& \mathrm{~N}-\mathrm{Mg} \quad-, 444 \quad-, 362 \quad 1 \\
& \mathrm{M}-\mathrm{Mg} \quad-, 467 \quad-, 487 \quad \text { a } \quad 1 \\
& \text { N - Mn } \quad, 131 \quad-, 263,033 \quad-, 134 \quad 1
\end{aligned}
$$

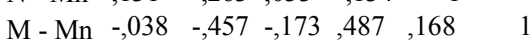

$$
\begin{aligned}
& \mathrm{N}-\mathrm{Pb} \quad, 113 \quad-, 012,282,376 \quad-, 250 \quad-, 028 \quad 1 \\
& \mathrm{M}-\mathrm{Pb} \quad, 528 \quad-, 075 \quad-, 324 \quad-, 121 \quad-, 192,177 \quad-, 180 \\
& \begin{array}{lllllllll}
\mathrm{N}-\mathrm{Zn} & \mathrm{a} & -, 185 & -, 277,068 & -, 015 & , 313 & , 043 & \text { a } & 1
\end{array} \\
& \begin{array}{lllllllll}
\mathrm{M}-\mathrm{Zn} & -, 370 & -, 082,466 & \mathrm{a} & -, 323,100 & \mathrm{a} & \mathrm{a} & -, 504 & 1
\end{array} \\
& \begin{array}{llllllllllll}
\mathrm{N}-\mathrm{Co} & \mathrm{a} & -, 276 & \text { a } & \text { 283 } & \text { 2062 } & -, 513 & , 095 & -, 462 & -, 457,267 & 1
\end{array} \\
& \text { M - Co , 204 } \\
& \begin{array}{llllllllllllll}
\mathrm{N}-\mathrm{Cd} & -, 228 & -, 159 & 049 & 233 & 216 & 286 & -4,412 & -, 392 & \text { a } & -, 117 & , 397 & 1
\end{array} \\
& \begin{array}{lllllllllllllll}
\mathrm{M}-\mathrm{Cd} & -, 291 & , 049 & -, 396 & -, 043 & -, 494,049 & 135 & -, 268 & -, 382,371 & -, 216 & -, 103,339 & 1
\end{array} \\
& \begin{array}{llllllllllllll}
\mathrm{N}-\mathrm{Cu} & -, 386 & -, 040 & \text { a } & 190 & , 414 & -, 384,041 & \text { a } & \text { a } & , 343 & \text { a } & -, 032,185 & -, 382 & 1
\end{array}
\end{aligned}
$$

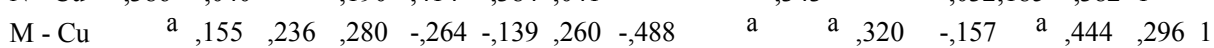

$\mathrm{a}_{*}: \mathrm{p}<0.05, * *: \mathrm{p}<0.01$ (Sperman's rank correlation coefficient).

$\mathrm{N}$, newborn; M, mother; Fe, Iron; Mg, Magnesium; Mn, Manganese; Pb, Lead; Zn, Zinc; Co, Cobalt; Cd, C admium; $\mathrm{Cu}$ Copper 
tracheoesophageal fistula. This relationship can lead to a breathing difficulty known as aspiration pneumonia if salivary from the upper pouch or stomach contents from the lower pouch enter the trachea and lungs. Esophageal atresia and tracheoesophageal fistula are congenital defects for which there are no recommended alternatives. There are no recognized measures to prohibit these congenital defects [4].

Researches on trace elements in health and illness have enabled us to understand the importance of them for life over the past 50 years. In the blood and tissues, $\mathrm{Cd}$ stimulates the formation of metallothioneins and reactive oxygen species (ROS) in this way cause to oxidative injury in erythrocytes and in several tissues [6-8].

$\mathrm{Mn}$ is a trace element required for health in trace quantity, but toxic at high doses. There are limited reports in the literature review about the effects of excessive oral exposure of humans [9]. An increase determined in Mn level of EA group compared to the control group $(p<0.01)$. There was a difference between their mothers and sick babies. The reason for this change in $\mathrm{Mn}$ level may arise from the change in the freeradical-scavenging activity of SOD.

$\mathrm{Pb}$ raises oxidative stress, affects endothelial function, promotes inflammation, down regulates nitric oxide production, and causes renal dysfunction [10]. The $\mathrm{Pb}$ is a toxic and carcinogenic metal $[11,12]$. An important decrease was detected in $\mathrm{Pb}$ level compared to the control group $(p<0.01)$. Additionally, serum $\mathrm{Pb}$ level was significantly lower in the newborns with EA than their mothers $(p<0.01)$ and not significantly different between the mothers of the healthy newborns and the mothers of the newborns. It is known that in increased $\mathrm{Pb}$ levels, lead passes the blood-brain barrier, in brain tissue.

Studies have confirmed the importance of $\mathrm{Zn}$ as a fundamental trace element in human metabolism [13-15]. Studies on zinc supplementation have shown a positive correlation on clinical findings and growth, especially amongst children who are stunted [16, 17]. The serum $\mathrm{Zn}$ level was significantly higher in serum of EA group than the control group $(\mathrm{P}<0.01)$.

Several physiological functions which can be important in immunological defense to pathogenic challenge may be impressed by the deficiency of cupper. It was reported that serum levels of $\mathrm{Cu}, \mathrm{Fe}$ and ceruloplasmin activity decreased in Cu-deficient animals [18]. A statistically significant increase determined in $\mathrm{Cu}$ level with esophageal atresia compared to the healthy newborns $(\mathrm{p}<0.01)$. This may be related to the higher ceruloplasmin levels in these groups. This is because the method that is used for copper measurement, determines the copper which is bound to ceruloplasmin $[19,20]$.

$\mathrm{Co}$ is a fundamental trace element of vitamin B12, which is necessary for foliate and fatty acid metabolism. Although cobalt is a necessary trace element, Co lack hasn't been reported in humans. Co can be measured in whole blood, serum and various tissues. There are no appointed markers or indicators of cobalt status [21, 22]. There was no important difference between any of the groups in serum Co levels. Co level was higher in EA group but it was not statistically significant $(p>0.01)$. Co is a natural element found throughout the environment. Respiration problems are the major effects noted from chronic exposure to Co by inhalation, with respiratory irritation, wheezing, asthma, pneumonia, and fibrosis noted [23].

$\mathrm{Mg}$ is the fourth most prodigal cation in the body and plays an essential role as an enzyme cofactor in the synthesis of proteins and mineral administration. Its metabolism is related to the bone and it is requisite to osteogenesis and mineralization of bones [24]. It has been reported that decreased $\mathrm{Mg}$ levels in the blood of people with active schizophrenia compared to normal and increased levels in people whose schizophrenia is in remission [25-27]. Statistically important increase was detected in serum $\mathrm{Mg}$ levels of newborns with EA compared to the control group $(\mathrm{p}<0.01)$.

$\mathrm{Fe}$ is a relatively abundant element in the universe. Iron nuclei are very stable. Fe is an essential component of plant and animal life, and is the key component of hemoglobin [28]. Although $\mathrm{Fe}$ is physiologically necessary, it is biochemically dangerous. $\mathrm{Fe}$ is an ultimate nutritional element for all life forms but excessive $\mathrm{Fe}$ and Fe deficiency also lead to oxidative DNA damage [29]. The mean concentration of $\mathrm{Fe}$ in the serum of EA patients was higher than $\mathrm{th}$ a $\mathrm{t}$ of the control group, but the difference was not significant $(p>0.01)$. It appeared that, Fe levels in the newborns with EA and their mothers had no effect on the development of congenital anomaly.

Cadmium is one of the most toxic environmental and industrial pollutants. Cadmium's industrial access arises from its matchless properties [11]. As a consequence, $\mathrm{Cd}$ increases enhanced lipid peroxidation and DNA damage; on the other hand decreases marked disturbances of antioxidant defense system $[6,19]$. As far as we know, there is no study examining $\mathrm{Cd}$ levels in $\mathrm{EA}$ in the literature. $\mathrm{Cd}$ level was found increased in esophageal atresia group than the control group $(p<0.01)$. Congenital anomalies in infants with 
high $\mathrm{Mg}$ and $\mathrm{Mn}$ values (in Esophagus atresia) can relate to the development.

There was a positive correlation between $\mathrm{Pb}$ and $\mathrm{Mg}, \mathrm{Cu}$ and $\mathrm{Cd}, \mathrm{Cu}$ and Fe levels in the newborns with EA and their mothers. There was a negative correlation between $\mathrm{Co}$ and $\mathrm{Fe}, \mathrm{Cd}$ and $\mathrm{Pb}$ levels in the newborns with EA. To date, no study examining the effects of mineral substance, trace element, heavy metal in esophageal atresia has been performed, as in the present study. Therefore, we could not have the chance to compare our results with the previous results.

\section{Conclusion}

Serum level of trace elements may be changed in patients with EA. In addition, serum $\mathrm{Cu}, \mathrm{Pb}, \mathrm{Zn}, \mathrm{Fe}, \mathrm{Mg}, \mathrm{Co}, \mathrm{Mn}$ and $\mathrm{Cd}$ might play a role in the patients of esophageal atresia. The current study is the first to show the presence of positive correlations among the serum $\mathrm{Cu}, \mathrm{Pb}, \mathrm{Zn}$, $\mathrm{Fe}, \mathrm{Cd}, \mathrm{Co}, \mathrm{Mn}, \mathrm{Mg}$ levels in EA patients. In this study, important data could be obtained about the relationship between mineral and heavy metal levels with esophageal atresia.

Financial Support: This research received no specific grant from any funding agency, commercial or not-for-profit sectors

Conflict of Interest: The authors declare no potential conflicts of interest with respect to the research, authorship, and/or publication of this article.

\section{References}

1. Goyal A, Jones MO, Couriel JM, Losty PD. Oesophageal atresia and tracheo-oesophageal fistula. Archives of disease in childhood Fetal and neonatal edition. 2006;91(5):F381-4.

2. Orenstein S, Peters J, Khan S. The digestive system. congenital anomalies: esophageal atresia and trachesophageal fistula. In Behrman RE, Kliegman RM, Jenson HB (eds.). Nelson textbook of pediatrics. Philadelphia, PA: WB Saunders. 2003;1219-1222.

3. Holder TM, Ashcraft KW, Sharp RJ, Amoury RA. Care of infants with esophageal atresia, tracheoesophageal fistula, and associated anomalies. The Journal of thoracic and cardiovascular surgery. 1987;94(6):828-35 .

4. Coran AG, Adzick NS, Krummel TM, Laberge JM, Shamberger RC, Caldamone AA. Pediatric Surgery. 7th ed. Saunders, Philadelphia. 2012.

5. Melek M, Demir H, Bilici S, Beger B, Cobanoglu U, Meral I, et al. Oxidative stress and antioxidant enzyme activities in newborns with oesophageal atresia and their mothers. The Journal of international medical research. 2012;40(1):249-57.
6. Demir H, Kanter M, Coskun O, Uz YH, Koc A, Yildiz A. Effect of black cumin (Nigella sativa) on heart rate, some hematological values, and pancreatic beta-cell damage in cadmium-treated rats. Biological trace element research. 2006;110(2):151-62

7. Sarkar S, Yadav P, Trivedi R, Bansal AK, Bhatnagar D. Cadmium-induced lipid peroxidation and the status of the antioxidant system in rat tissues. Journal of trace elements in medicine and biology : organ of the Society for Minerals and Trace Elements. 1995;9(3):144-9.

8. Simpkins C, Lloyd T, Li S, Balderman S, Metallothionein-induced increase in mitochondrial inner membrane permeability. The Journal of surgical research. 1998;75(1):30-4.

9. Kanabrocki EL, Case LF, Fields T, Graham L, Miller EB, Oester YT, et al. Manganese and copper levels in human urine. Journal of nuclear medicine : official publication, Society of Nuclear Medicine. 1965;6(11):780-91

10. Lustberg M, Silbergeld E. Blood lead levels and mortality. Archives of internal medicine. 2002;162(21):2443-9.

11. Messner B, Knoflach M, Seubert A, Ritsch A, Pfaller K, Henderson B, et al. Cadmium is a novel and independent risk factor for early atherosclerosis mechanisms and in vivo relevance. Arteriosclerosis, thrombosis, and vascular biology. 2009;29(9):1392-8.

12. Bilici M, Atasoy N, Kavak S, Demir H. Examining the level of some elements (Zinc, Chromium, Lead and Cadmium) and some liver enzymes (lower and upper) in the blood-serum of the workers at the car-reparing shops in the vicinity of Van. Fresenius Environ. Bull. 2012;4:904-905

13. Gibson RS, Hess SY, Hotz C, Brown KH. Indicators of zinc status at the population level: a review of the evidence. The British journal of nutrition. 2008;99 Suppl 3:S14-23

14. Heyland DK, Jones N, Cvijanovich NZ, Wong H. Zinc supplementation in critically ill patients: a key pharmaconutrient? JPEN Journal of parenteral and enteral nutrition. 2008;32(5):509-19

15. Stamoulis I, Kouraklis G, Theocharis S. Zinc and the liver: an active interaction. Digestive diseases and sciences. 2007;52(7):1595-612.

16. Fischer Walker CL, Black RE. Functional indicators for assessing zinc deficiency. Food and nutrition bulletin. 2007;28(3 Suppl):S454-79.

17. Ramakrishnan U, Nguyen P, Martorell R. Effects of micronutrients on growth of children under $5 \mathrm{y}$ of age: meta-analyses of single and multiple nutrient interventions. The American journal of clinical nutrition. 2009;89(1):191-203

18. Andersen HS, Gambling L, Holtrop G, McArdle HJ. Effect of dietary copper deficiency on iron metabolism in the pregnant rat. The British journal of nutrition. 2007;97(2):239-46. 
19. Carson BL, Ellis HV, Mc Cann JL, Antimony. In: Toxicology and Biological Monitoring of Metals in Humans. Chelsea, MI: Lewis. 1986;21-26.

20. Ilhan N, Ilhan N, Simsek M. The changes of trace elements, malondialdehyde levels and superoxide dismutase activities in pregnancy with or without preeclampsia. Clinical biochemistry. 2002;35(5):393-7.

21. Paternain JL, Domingo JL, Corbella J. Developmental toxicity of cobalt in the rat. Journal of toxicology and environmental health. 1988;24(2):193-200.

22. Pedigo NG, George WJ, Anderson MB. Effects of acute and chronic exposure to cobalt on male reproduction in mice. Reproductive toxicology. 1988;2(1):45-53

23. Alk1s I, Kavak S, Meral I, Oto G, Demir H. The effect of drospirenone/estradiol (angeliq ${ }^{\circledR)}$ on catalase and carbonic anhydrase enzyme activities with some biochemical element concentrations in ovariectomized rat model. Fresenius Environ. Bull. 2011;10:2543-2545.

24. Rahnama M, Marciniak A. Influence of estrogen deficiency on the level of magnesium in rat mandible and teeth. Bull. Vet. Inst. Pulawy. 2002;46:267-271.
25. Collery P, Anghileri LJ, Coudoux P, Durlach J. Magnesium and cancer: clinical data. Magnesium Bull. $1981 ; 3: 11-20$

26. Cobanoglu U, Demir H, Sayir F, Duran M, Mergan D. Some mineral, trace element and heavy metal concentrations in lung cancer. Asian Pacific journal of cancer prevention : APJCP. 2010;11(5):1383-8.

27. Arslan M, Demir H, Arslan H, Gokalp AS, Demir C. Trace elements, heavy metals and other biochemical parameters in malignant glioma patients. Asian Pacific journal of cancer prevention : APJCP. 2011;12(2):44751.

28. Casanueva E, Viteri FE. Iron and oxidative stress in pregnancy. The Journal of nutrition. 2003;133(5 Suppl 2):1700S-8S

29. Ames BN. DNA damage from micronutrient deficiencies is likely to be a major cause of cancer. Mutation research. 2001;475(1-2):7-20.

Copyright (C) 2014 The Author(s); This is an open-access article distributed under the terms of the Creative Commons Attribution License (http://creativecommons.org/licenses/by/4.0), which permits unrestricted use, distribution, and reproduction in any medium, provided the original work is properly cited. 